\title{
RESEARCH PAPER \\ THE EFFECTS OF SEWAGE EFFLUENT DISCHARGES ON THE WATER QUALITY OF WUPA RIVER IN ABUJA, NIGERIA
}

\author{
G.D. Akpen ${ }^{1}$, E. J. Ekanem ${ }^{2}$ and J. C. Agunwamba ${ }^{3}$ \\ ${ }^{I}$ Department of Civil Engineering, University of Agriculture, Makurdi \\ ${ }^{2}$ Department of Civil Engineering, University of Agriculture, Makurdi \\ ${ }^{3}$ Department of Civil Engineering, University of Nigeria, Nsukka \\ Correspondence author: deliakpen@yahoo.com
}

\begin{abstract}
The effect of sewage effluents discharge on water quality of the receiving river in the Wupa area of Abuja was studied to determine the assimilative capacity of the receiving river in event of shock load due to treatment plant failure. The river passes through Idu industrial area of Abuja from where effluent from Wupa sewage treatment plant is discharged. Water samples were taken from six stations along the river reach of 16 kilometres within the vicinity of the treatment plant. Both the effluents and the water samples at six selected points along the river were analysed for pH, electrical conductivity (EC), turbidity, biochemical oxygen demand (BOD) and dissolved oxygen (DO). The results were compared with the standards set by National Environmental Standards and Regulations Enforcement Agency (NESREA) for waste water. The result indicates that the BOD load on the river was within the stipulated limit and there exist a moderate degree of self-purification in the river. The study concluded that the river can withstand BOD shock loadings of up to $44.3 \mathrm{mg} / \mathrm{L}$ from the treatment plant without injuring the assimilative capacity of the river.
\end{abstract}

Keywords: Water Quality, Biochemical Oxygen Demand, Dissolved Oxygen, Wupa River, Assimilative Capacity

\section{INTRODUCTION}

Water quality monitoring forms an important component of managing the water quality of a river in terms of assessing the health conditions of that river in order to ensure a healthy aquatic environment. Certain water quality indicators such as dissolved oxygen (DO), temperature, biochemical oxygen demand (BOD) etc, need to be determined and compared with specified limits set by regulatory agencies such as the National Environmental Standards and Regulations Enforcement Agency (NESREA, 2011) in Nigeria.

The solubility of oxygen in water for instance, depends on temperature. At high temperature, when bacterial actions are most rapid, the solubility of oxygen is reduced. Hence, conditions 


\section{Akpen et al.}

in a polluted river usually are worse in warm weather; particularly if it coincides with low flow season (Ogbaji et al., 2013). The rate of biodegradation is accelerated or retarded by ambient temperature which affects the values of de-oxygenation and re-aeration rates.

Biochemical oxygen demand (BOD), chemical oxygen demand (COD), total oxygen demand and dissolved oxygen (DO) are the common parameters used in assessing the assimilative capacity of a river. The BOD measures the amount of oxygen utilized by micro-organisms during the oxidation of organic materials (Rao, 2006). It gives an indication of water pollution potential of a given organic waste. The test has its widest application in measuring waste loading to treatment plants and in evaluating the efficiency of such treatment systems.

Water quality of various rivers and streams have been studied and monitored. Akpen and Eze (2006) conducted water quality assessment of River Benue at Makurdi with the aim of using the water quality parameters to develop a model for prediction. Apeh and Ekenta (2012) conducted a study on the surface water quality of Benue River within the reach of the Makurdi brewery. In the study, water quality monitoring was carried out over a period of six months for point and non-point source discharges. The study concluded that pollution in River Benue is influenced by natural regimes such as rainfall and discharges of effluents. Physical and chemical pollutions increased with rainfall while microbial pollution is inversely proportional to rainfall. Similarly, Ogbaji et al. (2013) worked on the same river and applied a mathematical model to describe the self-purification of the River Benue, and concluded that selfpurification of the polluted river is possible. Ogedengbe and Akinbile (2010) carried out a comparative assessment of industrial and agricultural effluents on the surface water of Ona stream in Ibadan, Nigeria with the aim of identifying major pollutants, their effects on water qualities and to ascertain the potential of using the polluted surface water for irrigation pur- poses. The result showed that the surface water from the Ona stream was unsuitable for irrigation due to the attendant health hazards associated with the negative effects of pathogens and toxic chemicals in the discharged wastewater.

Adedokun and Agunwamba (2013) modelled the effect of industrial effluents on water quality of River Challawa in Nigeria. The study investigated the physicochemical characteristics associated with industrial effluents from the Challawa and Sharada Industrial Estate in Kano State, Nigeria and the effect on water quality downstream of River Challawa for a period covering wet and dry seasons. The findings identified high BOD load and low dissolved oxygen level, as contributing to a polluted stream with poor assimilatory capacity.

Ubwa et al. (2013) carried out assessment of surface water around Gboko abattoir to determine the pollution status of water around the area. The study showed that the values of measured parameters (BOD, DO, etc), were above regulatory standards. The results also showed that the activities at the abattoir were contributing to the pollution load of water in the area, and recommended for close monitoring by the relevant agencies in order to prevent further environmental problems and the attendant health hazards in the future. Chindah et al. (2011) carried out a study on the water quality of streams receiving municipal waste in Port Harcourt, Nigeria and found that the levels of DO observed for the study streams were so low as to support aquatic life including fish. The low level oxygen was attributed to the increased concentration of BOD, which tends to swiftly deplete oxygen in the stream.

Paul (2011) studied the impact of industrial effluents on water quality of receiving streams in Nakawa-Ntinda, Uganda with the aim of developing preventive measures. Water quality parameters were assessed and the investigation found that a high degree of pollution in the stream exists and made recommendations on reduction of pollution in the stream. Sharma et al. (2003) monitored the water quality of Hathli 
stream in lower Himalayan Region for parameters of BOD and DO beside others, and established that those parameters were mainly critical during very low discharges.

In Nigeria, the power supply has been quite unsteady. In the event of a disruption in the power supply for one hour, about $1375 \mathrm{~m}^{3}$ of waste water will enter the Wupa River without treatment which could be dangerous to the river's re-aeration capacity. The water quality was thus investigated to determine the potential of the river recovering in the event of municipal waste spills and the effect on the re-aeration capacity of the river.

\section{MATERIALS AND METHOD}

\section{Study area}

The study area lies between longitude $7^{0} 17^{\prime}$ 00 ' $\mathrm{E}$ and $7^{0} 22^{\prime} 12^{\prime \prime} \mathrm{E}$ and latitude $8^{0} \quad 56^{\prime}$ $48^{\prime} ' \mathrm{~N}$ and $9^{0} 01^{\prime} 48^{\prime}, \mathrm{N}$. The administrative map of the Federal Capital Territory (FCT) depicting the location of the Wupa River is presented in Fig. 1. Wupa River is part of the Jabi River watershed in Abuja. The reach of the river under study covers a total length of 16 $\mathrm{km}$. The river is narrow with maximum dry weather flow width varying from $10 \mathrm{~m}$ to $20 \mathrm{~m}$. The river channel bed outcrops indicate medium roughness and the degree of sinusoidality is low to moderate with some few sharp bends. The temperature in the area varies from $27^{\circ} \mathrm{C}$ to $36^{\circ} \mathrm{C}$ with an average value of $29^{\circ} \mathrm{C}$. Rainfall varied from a monthly depth of $10 \mathrm{~mm}$ to 68 $\mathrm{mm}$ for the year 2012 .

The Wupa Sewage Water Treatment plant is an oxidation ditch type. It was designed to treat waste generated from Abuja city. It has three operating units with one -unit being under operation while the remaining two units are standby in the event of failure of one unit. The

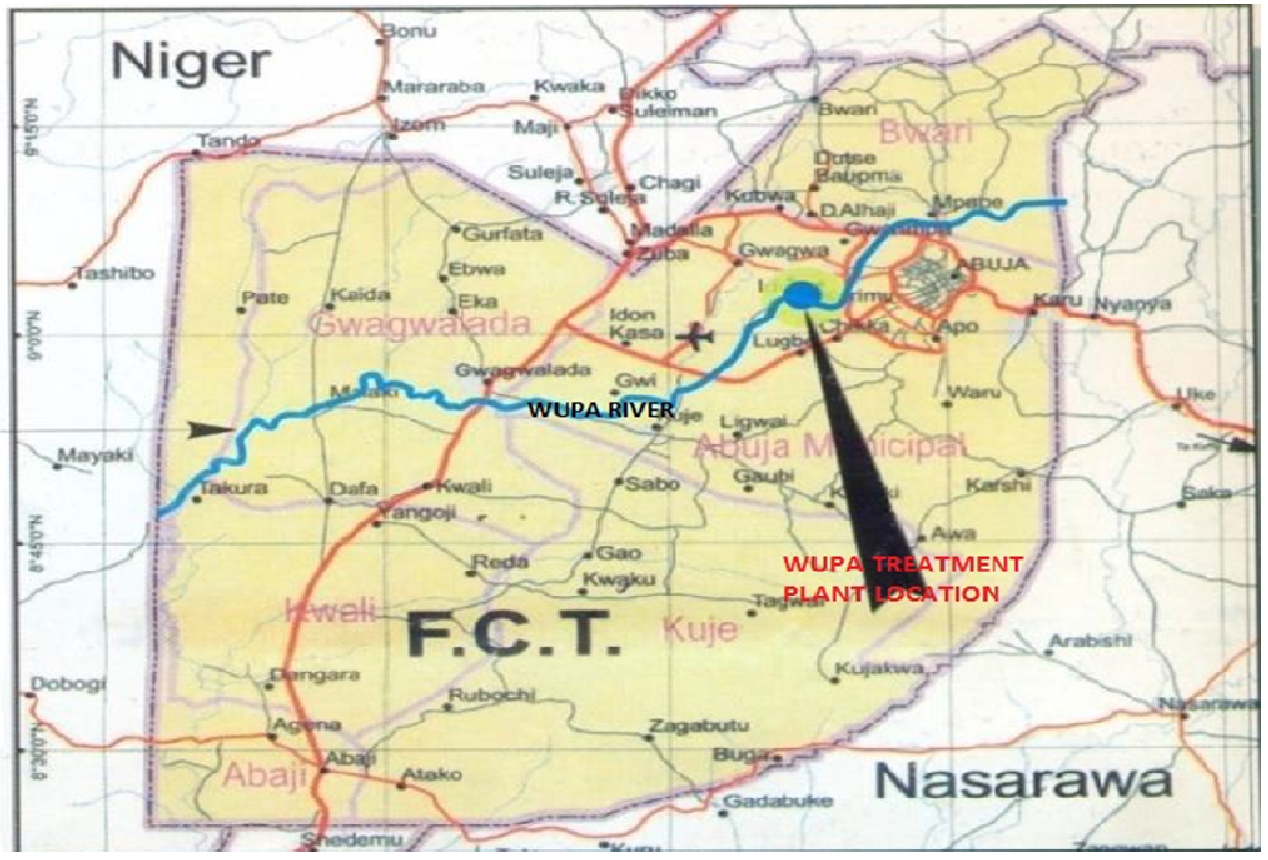

Fig. 1: Administrative map of Abuja showing the location of Wupa River 
plants were designed for a full capacity operation of $131,250 \mathrm{~m}^{3}$ of waste per day, though at the moment, it is operating below designed capacity.

\section{Materials}

The materials and equipment used in carrying out the field operation for data collection are listed in Table 1 below.

\section{Sampling locations}

Seven sampling points (Numbered ST.1 to ST.6 and STS), were identified and their coordinates determined along the reach of the river (see Table 2). The sampling points were selected based on accessibility to measurement sites. Water samples were collected from each of those sites for water quality measurements. The coordinates of sampling points (determined using Garmin GPS model 60) are given in Table 2 for the month of September, 2012.

\section{Sampling design and method}

Samples were collected in September, 2012, which represents the peak rainy season and in January, 2013 for the dry season. Measurements were also conducted in the month of May, 2013, representing the start of the rainy period in the area. Prior to sample collection, 75 centi-litre plastic bottles were washed with dilute acid followed by distilled water and dried at each sampling location. Before collecting samples into the bottles for analysis, they were rinsed twice with the water to be collected. The samples were labelled with date, time and sample location number and taken to the Wupa sewage treatment laboratory for analysis.

\section{Laboratory analysis}

The following physico-chemical properties of each water sample were investigated using standard methods (APHA, 1995): temperature, turbidity, conductivity, total dissolved solids, $\mathrm{pH}$, biochemical oxygen demand (BOD) and dissolved oxygen (DO).

\section{Determination of hydrogeometric properties of the River Channel}

Hydrogeometric properties of the river determined included flow velocity, depth, cross sectional area and discharge. The discharge was determined using the velocity-area method. The value of $\mathrm{K}_{1}$ was estimated based on Chin (2006) as indicated in Table $3 . \mathrm{K}_{2}$ was computed based on Equation 1 (O'Connor and Dobbins, 1958).

$\mathrm{K}_{2}=3.93 \frac{u^{1.5}}{H^{: .5}}$

Where, $\mathrm{U}$, is the velocity in $\mathrm{m} / \mathrm{sec}$ and $\mathrm{H}$, is the depth in meters.

The dispersion coefficient $\left(\mathrm{E}_{\mathrm{x}}\right)$ was calculated

Table.1: Materials used in the study

\begin{tabular}{|c|c|c|}
\hline PARAMETER & MEASURED WITH & USED FOR \\
\hline DO & Dissolved Oxygen Meter Model 9071 & Model calibration \\
\hline $\mathrm{BOD}(\mathrm{mg} / \mathrm{L})$ & $\begin{array}{l}\text { Respirometer, BOD Bottles, } \\
\text { Model OxiTop }\end{array}$ & Model Calibration \\
\hline River Temp & Thermometer - Hand held mercury & Calibration of coefficients \\
\hline Conductivity & Conductivity/TDS meter-DiST3 & \\
\hline Stream Velocity & $\begin{array}{l}\text { Floating rubber corks, Measuring Tape, } \\
\text { Timer }\end{array}$ & Model calibration \\
\hline Depth & Graduated wading rod & Depth Measurement \\
\hline Elevation & Garmin GPS 60 & Slope calculation \\
\hline Coordinates & Garmin GPS 60 & Point identification \\
\hline
\end{tabular}


Effect of sewage effluents discharge on water quality...

Table. 2: Coordinates and elevation of sampling points (GPS)

\begin{tabular}{|c|c|c|c|c|c|}
\hline \multirow[t]{2}{*}{$\mathbf{S} / \mathbf{N}$} & \multirow[t]{2}{*}{ Site No. } & \multicolumn{2}{|c|}{ GPS Coordinates Point } & \multirow{2}{*}{$\begin{array}{l}\text { Elevation } \\
\quad(\mathrm{m})\end{array}$} & \multirow[t]{2}{*}{ Remarks } \\
\hline & & Latitude & Longitude & & \\
\hline 1 & ST.1 & 0321884 & 0997488 & 381 & $\begin{array}{l}\text { Upstream station of Wupa River before } \\
\text { discharge point }\end{array}$ \\
\hline 2 & WTP & & & & Effluent discharge point location \\
\hline 3 & ST.2 & 0321868 & 0997595 & 380 & $\begin{array}{l}\text { Downstream of Wupa river after effluent } \\
\text { discharge point }\end{array}$ \\
\hline 4 & STS & 0321529 & 0998645 & 380 & Station at Piqwi village stream \\
\hline 5 & ST.3 & 0321728 & 0998457 & 379 & \\
\hline 6 & ST.4 & 0318630 & 0997575 & 374 & Station downstream at Hulumi village \\
\hline 7 & ST.5 & 0312825 & 0990117 & 339 & Station at Gosa village downstream \\
\hline 8 & ST.6 & 0312825 & 0990117 & 305 & $\begin{array}{l}\text { Under Gosa Bridge by Airport Road, Abuja. } \\
\text { Downstream point }\end{array}$ \\
\hline
\end{tabular}

Date of Sampling: 19-09-2012

Key $:$ WTP = Effluent discharge point location; STS = Test Station; ST.1, ST.2 ... = Station identification number 1, 2, etc

Table 3: Typical deoxygenation constants

\begin{tabular}{ll}
\hline Type of Water & \\
\hline Untreated Waste water & $0.35-0.70$ \\
Treated Waste water & $0.10-0.35$ \\
Polluted River & $0.10-0.25$ \\
Unpolluted River & less than -0.05 \\
\hline
\end{tabular}

Source: Chin (2006)

using Equation (2) expressed as:

$E_{x}=2.1 \times n \times u_{x} \cdot H^{5 / 6}$ with unit of $\mathrm{m}^{2} / \mathrm{sec}$

Where, $\mathrm{u}_{\mathrm{x}}$ is the longitudinal velocity, $\mathrm{H}$ is the depth, and $n$ the manning's roughness.

RESULT AND DISCUSSION

Influent BOD and effluent discharges data from Wupa treatment plant.

The Wupa Sewage treatment plant maintains data base on the waste inflows and the effluent out of the plant. All waste water quality parameters available were collected. However, there was no information regarding the Wupa river flows whether on short or long term. The average daily waste inflows into the plant are indicated in Table 4. Effluent water qualities discharged into the river are given in Table 5 . The overall treatment capacity of the plant is $131,250 \mathrm{~m}^{3} /$ day. However, the present treatment plant operates at about one fourth $(33,000$ $\mathrm{m}^{3} /$ day), of the total plant installed capacity.

\section{Water quality results}

The results of the water quality tests are given in Tables 6-8 and Figs. 2 and 3. A comparison of the BOD (Fig. 2) and DO (Fig. 3) for the 


\section{Akpen et al .}

Table 4: Influent load into the treatment plant

\begin{tabular}{lc}
\hline \multicolumn{1}{c}{ Parameters } & Values $(\mathbf{m g} / \mathbf{L})$ \\
\hline Biochemical oxygen demand (BOD) & 180 \\
Dissolved Oxygen (DO) & 2.5 \\
Chemical oxygen demand (COD) & 400 \\
Total suspended solids (TSS) & 170 \\
Total phosphate (TP) & 1.2 \\
Nitrate as Nitrogen $\left(\mathrm{NO}_{3}{ }^{-\mathrm{N}}\right)$ & 3.25 \\
Actual inflow to plant & \\
\hline
\end{tabular}

Source: Wupa Sewage Treatment Plant, WUPA (2012)

Table 5: Effluents load into the Wupa River

\begin{tabular}{lc}
\hline \multicolumn{1}{c}{ Parameters } & Value $(\mathbf{m g} / \mathbf{L})$ \\
\hline BOD & 1 \\
& 1 \\
$\mathrm{DO}$ & $7-8$ \\
$\mathrm{COD}$ & 25 \\
$\mathrm{TSS}$ & 13 \\
$\mathrm{TP}$ & 3.0 \\
$\mathrm{NO}_{3}{ }^{-\mathrm{N}}$ & 7.0 \\
Actual discharge to river & $28,000 \mathrm{~m}^{3} /$ day $=7.778 \mathrm{~m}^{3} / \mathrm{s}$ \\
\hline
\end{tabular}

Source: Wupa Sewage Treatment Plant, WUPA (2012)

Table 6: Field water quality data -19th September, 2012 measurements

\begin{tabular}{lccccccc}
\hline Water Quality Parameters & ST.1 & ST.2 & ST.3 & ST.4 & ST.5 & ST.6 & STS \\
\hline Temperature ${ }^{0} \mathrm{C}$ & 27.6 & 28.0 & 27.7 & 27.1 & 28.0 & 27.8 & 27.7 \\
Conductivity $(\mu \mathrm{S} / \mathrm{cm})$ & 170 & 168 & 168.5 & 171 & 170.8 & 167.7 & 169 \\
BOD $(\mathrm{mg} / \mathrm{L})$ & 7.0 & 10.0 & 9.0 & 7.0 & 9.0 & 14.0 & 13.0 \\
DO $(\mathrm{mg} / \mathrm{L})$ & 8.7 & 7.8 & 7.85 & 8.0 & 8.05 & 7.8 & 7.45 \\
pH & 7.43 & 7.32 & 7.30 & 7.25 & 7.35 & 7.30 & 7.25 \\
Saturated DO $(\mathrm{mg} / \mathrm{L})$ & 7.78 & 7.83 & 7.77 & 7.86 & 7.83 & 7.75 & 7.77 \\
Ultimate BOD $(\mathrm{mg} / \mathrm{L})$ & 11.1 & 15.8 & 14.2 & 11.1 & 14.2 & 22.1 & 20.6 \\
\hline
\end{tabular}


Effect of sewage effluents discharge on water quality... 92

Table 7: Field water quality data- 20th January, 2013 measurements

\begin{tabular}{llllllll}
\hline Water Quality Parameters & ST.1 & ST.2 & ST.3 & ST.4 & ST.5 & ST.6 & STS \\
\hline Temperature ${ }^{0} \mathrm{C}$ & 26.5 & 26.5 & 26.5 & 27 & 27 & 27 & 27 \\
Conductivity $(\mu \mathrm{S} / \mathrm{cm})$ & 217 & 240 & 238.5 & 211.0 & 223.8 & 205.7 & 198 \\
BOD $(\mathrm{mg} / \mathrm{L})$ & 16 & 18 & 17 & 16 & 20 & 21 & 25 \\
DO $(\mathrm{mg} / \mathrm{L})$ & 8.1 & 8.4 & 8.0 & 8.1 & 7.85 & 7.9 & 6.95 \\
Saturated DO $(\mathrm{mg} / \mathrm{L})$ & 8.1 & 8.1 & 8.1 & 8 & 8 & 8 & 8 \\
$\mathrm{pH}$ & 7.2 & 7.28 & 7.23 & 7.15 & 7.25 & 7.20 & 7.05 \\
Ultimate BOD $(\mathrm{mg} / \mathrm{L})$ & 25 & 28.5 & 26.9 & 25 & 31.6 & 33 & 39.5 \\
\hline
\end{tabular}

Key: STS = Test Station, ST.1, ST.2 ... = Station identification number 1, 2, etc

Table 8: Field Water Quality Data-17th May, 2013 Measurements

\begin{tabular}{llllllll}
\hline Water Quality Parameters & ST.1 & ST.2 & ST.3 & ST.4 & ST.5 & ST.6 & STS \\
\hline Temperature ${ }^{0} \mathrm{C}$ & 27 & 27.5 & 27.8 & 27.8 & 28.0 & 27.8 & 28.0 \\
Conductivity $(\mu \mathrm{S} / \mathrm{cm})$ & 190 & 170 & 200.5 & 189 & 188 & 185.8 & 177.72 \\
BOD $(\mathrm{mg} / \mathrm{L})$ & 28 & 25 & 27 & 23 & 18 & 25 & 20 \\
DO $(\mathrm{mg} / \mathrm{L})$ & 5.8 & 5.6 & 5.4 & 5.3 & 6.3 & 5.5 & 5.6 \\
Saturated DO $(\mathrm{mg} / \mathrm{L}$ & 7.83 & 7.83 & 7.9 & 7.8 & 7.83 & 7.75 & 7.82 \\
pH & 7.2 & 6.98 & 7.2 & 7.15 & 7.0 & 7.0 & 7.2 \\
Ultimate BOD $(\mathrm{mg} / \mathrm{L})$ & 44.3 & 39.5 & 42.7 & 36.4 & 28 & 39.5 & 31.5 \\
\hline
\end{tabular}

Key: $S T S=$ Test Station, ST.1, ST.2 ... = Station identification number 1, 2, etc

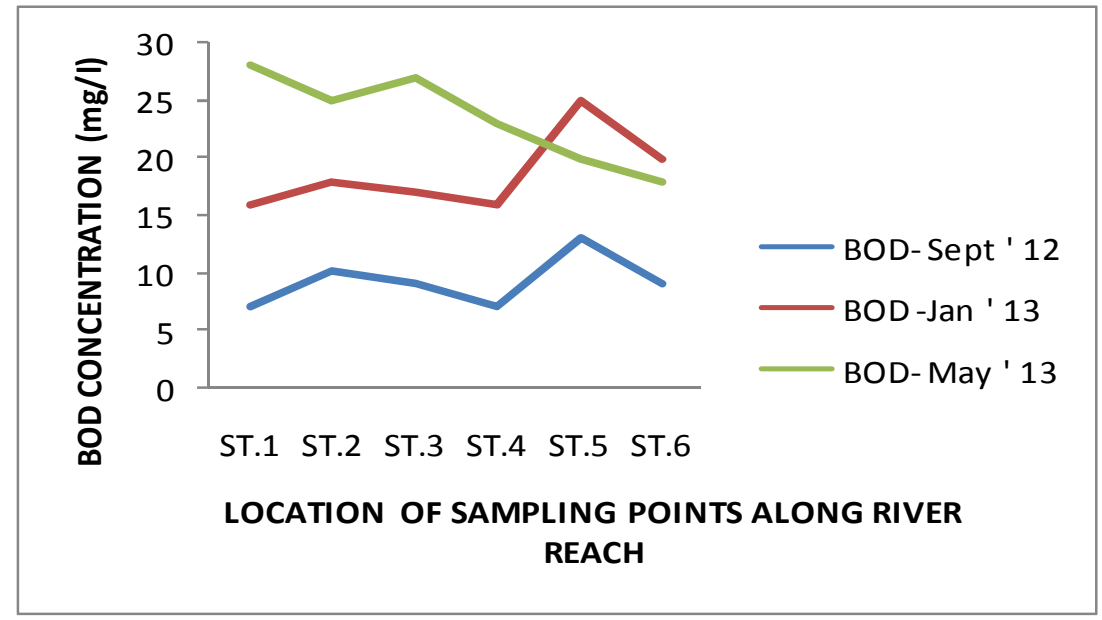

Fig. 2: Curves comparing BOD variation for Sept' 12; Jan'13; May'13 


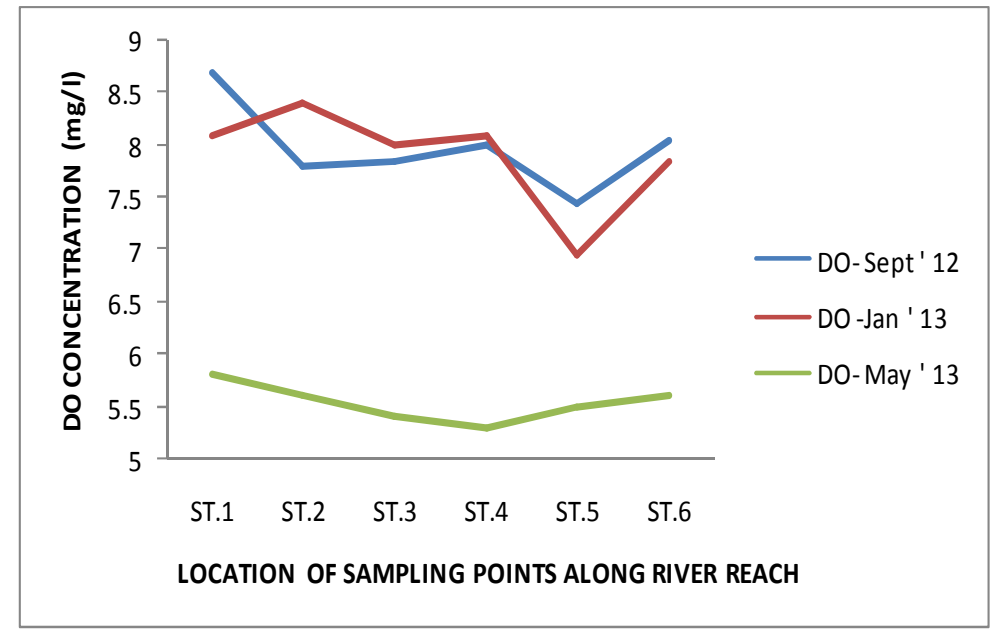

Fig. 3: Curves comparing DO variation for Sept' 12; Jan'13; May'13

months of September, 2012, January, 2013 and May, 2013 indicates that the BOD loads in May, 2013 were higher than those of January, 2013 and September, 2012 at the various stations. This may be due to effect of surface run off occasioned by the onset of rainy season and with the low volume of flow in the river, BOD introduced from the treatment plant was not well diluted compared to the rainy season (September, 2012). The DO in May is lower than that of the other two months corresponding to the high BOD load in the same month.

\section{Hydraulic data}

The field hydraulic data collected include the river velocity, the channel width and the depth of river flow. The results of the processed data are summarized in Tables 9-11. From the field measurements, the width of Wupa river channel varies from 5 to $22 \mathrm{~m}$ during peak flow and 2$12 \mathrm{~m}$ during normal flow period, the river can be taken as a small river.

\section{Self-purification potential of Wupa River}

Self-purification potential is assessed based on the ratio of re-aeration constant to that of the de-oxygenation constant (Agunwamba, 2007;
Garg, 1986). From Tables 9-11, the selfpurification ratio, $\mathrm{f}$; in all cases exceeded the minimum value of $2(17 \leq \mathrm{f} \leq 90)$ needed to improve the oxygen level in a river. This is an indication that the river possesses high selfpurification potential. Thus, Wupa River has a fair assimilative capacity that can withstand some level of unexpected spills from the plant. This ability to undergo self-purification is aided by the presence of rock outcrops and boulders along the river channel.

\section{CONCLUSION AND RECOMMENDA- TION}

From the study, it is concluded that there exists a seasonal variation in the water quality of River Wupa. The BOD loads are higher during dry season than in the wet season, and that the variation is due to dilution process during the rainy season. However, the river possesses high assimilative capacity both in the rainy and dry seasons and can absorb reasonable shock BOD loadings (up to $44.3 \mathrm{mg} / \mathrm{L}$ ) from the wastewater treatment plant without adversely affecting its water quality. It is recommended that the water quality parameters of Wupa River should be continuously monitored for its oxygen demands 
Effect of sewage effluents discharge on water quality... 94

Table 9: River hydraulic parameters-19th September, 2012 measurements

\begin{tabular}{llllllll}
\hline $\begin{array}{l}\text { Hydraulic } \\
\text { Parameters }\end{array}$ & ST.1 & ST.2 & ST.3 & ST.4 & ST.5 & ST.6 & STS \\
\hline Elevation $(\mathrm{m})$ & & & & & & & \\
Length (m) & 381 & 380 & 379 & 374 & 339 & 305 & 380 \\
Velocity (m/s) & 0 & 502 & 1000 & 1510 & 8000 & 5000 & - \\
Depth (H) m & 4 & 2.3 & 1.89 & 2.0 & 1.5 & 1.82 & 1.67 \\
Sect. Area $\left(\mathrm{m}^{2}\right)$ & 0.45 & 1.5 & 1.45 & 1.11 & 1.25 & 0.8 & 0.2 \\
Flow $\left(\mathrm{m}^{3} / \mathrm{s}\right)$ & 2.1 & 8.81 & 12.92 & 13.51 & 21.33 & 15.52 & 4.17 \\
Re-oxygenation Rate $\mathrm{K}_{2}$ (per day) & 12.39 & 20.22 & 24.49 & 27.07 & 31.99 & 28.22 & 6.95 \\
De-oxygenation rate, $\mathrm{K}_{1}($ per day & 0.20 & 3.24 & 3.1 & 4.75 & 3.49 & 7.41 & - \\
Dispersion Coefficient $\left(\mathrm{m}^{2} / \mathrm{s}\right)$ & 0.067 & 0.138 & 0.122 & 0.10 & 0.096 & 0.084 & \\
Self-Purification Ratio, $\mathrm{f}\left(\mathrm{K}_{2} / \mathrm{k}_{1}\right)$ & 65 & 16.2 & 15.5 & 23.7 & 17.4 & 37.01 & \\
\hline
\end{tabular}

Key: STS = Test Station; ST.1, ST.2 ... = Station identification number 1, 2, etc

Table 10: River hydraulic parameters- $7^{\text {th }}$ January, 2013 measurements

\begin{tabular}{llllllll}
\hline $\begin{array}{l}\text { Hydraulic } \\
\text { Parameters }\end{array}$ & ST.1 & ST.2 & ST.3 & ST.4 & ST.5 & ST.6 & STS \\
\hline Elevation (m) & 381 & 380 & 379 & 374 & 339 & 305 & 380 \\
Length (intervals) $(\mathrm{m})$ & 0 & 502 & 1000 & 1510 & 8000 & 5000 & 11000 \\
Velocity, u (m/s) & 0.88 & 3.25 & 1.80 & 1.89 & 1.65 & 1.39 & 1.6 \\
Depth (H) m & 0.45 & 0.55 & 0.65 & 0.45 & 0.60 & 0.80 & 0.2 \\
Sect. Area, A (m $\left.{ }^{2}\right)$ & 1.2 & 2.52 & 4.88 & 5.47 & 6.09 & 7.6 & 0.57 \\
Flow $\left(\mathrm{m}^{3} / \mathrm{s}\right)$ & 1.05 & 8.2 & 8.79 & 10.34 & 10.03 & 10.56 & 1.37 \\
Re-oxygenation Rate, $\mathrm{K}_{2}($ per day) & 12.18 & 17.37 & 10.06 & 9.5 & 10.85 & 6.47 & 17.89 \\
De-oxygenation rate, $\mathrm{K}_{1}($ per day) & 0.20 & 0.20 & 0.20 & 0.2 & 0.20 & 0.20 & 0.20 \\
Dispersion Coefficient $\left(\mathrm{m}^{2} / \mathrm{s}\right)$ & 0.031 & 0.071 & 0.061 & 0.022 & 0.055 & 0.064 & 0.046 \\
Self-Purification Ratio, $\mathrm{f}\left(\mathrm{K}_{2} / \mathrm{k}_{1}\right)$ & 60 & 88 & 50 & 47 & 54 & 32 & \\
\hline
\end{tabular}

Key: STS = Test Station,ST.1, ST.2 ... = Station identification number 1, 2, etc

Table 11: River hydraulic parameters-17 ${ }^{\text {th }}$ May, 2013 Measurements

\begin{tabular}{|c|c|c|c|c|c|c|c|}
\hline $\begin{array}{l}\text { Hydraulic } \\
\text { Parameters }\end{array}$ & ST.1 & ST.2 & ST.3 & ST.4 & ST.5 & ST.6 & STS \\
\hline Elevation (m) & 381 & 380 & 379 & 374 & 339 & 305 & 380 \\
\hline Length (intervals) (m) & 0 & 500 & 1000 & 1500 & 8000 & 5000 & - \\
\hline Velocity $(\mathrm{m} / \mathrm{s})$ & 0.72 & 0.98 & 1.3 & 1.1 & 1.0 & 0.9 & 0.95 \\
\hline Depth $(\mathrm{H}) \mathrm{m}$ & 0.45 & 0.55 & 0.65 & 0.2 & 0.60 & 0.80 & 0.45 \\
\hline Sect. Area $\left(\mathrm{m}^{2}\right)$ & 1.2 & 2.52 & 4.88 & 0.57 & 6.09 & 7.6 & 5.47 \\
\hline Flow $\left(\mathrm{m}^{3} / \mathrm{s}\right)$ & 1.05 & 8.2 & 8.79 & 1.37 & 10.03 & 10.56 & 10.34 \\
\hline Re-oxygenation Rate $\mathrm{K}_{2}$ (per day) & 7.1 & 2.6 & 4.08 & 3.85 & 7.0 & 13.6 & 13 \\
\hline De-oxygenation rate $\mathrm{K}_{1}$ (per day) & 0.15 & 0.15 & 0.15 & 0.15 & 0.15 & 0.15 & 0.15 \\
\hline Dispersion Coefficient $\left(\mathrm{m}^{2} / \mathrm{s}\right)$ & 0.031 & 0.043 & 0.049 & 0.018 & 0.053 & 0.047 & 0.029 \\
\hline Self-Purification Ratio, $\mathrm{f}\left(\mathrm{K}_{2} / \mathrm{k}_{1}\right)$ & 47 & 17 & 27 & 26 & 47 & 90 & \\
\hline
\end{tabular}

Key $:$ STS = Test Station; ST.1, ST.2 ... = Station identification number 1, 2, etc 


\section{Akpen et al.}

\section{REFRENCES}

Adedokun, T. A. and Agunwamba, J. C. (2013). "Modeling the Effect of Industrial Effluents on Water Quality: A Case Study of River Challawa in Nigeria." International Journal of Modern Engineering Research, 3 (5):2797-2803.

Agunwamba, J. C. (2007). Engineering Mathematical Analysis. De Adroit Innovation, Enugu, Nigeria.

Akpen, G. D. and Eze, R. A. M. (2006). "Water Pollution Modelling of the River Benue in the Reach of Makurdi Town." NSE Technical Transactions, 41(2):1-20.

Apeh, S. and Ekenta, O. E. (2012).“Assessment of Surface Water Quality of River Benue at Makurdi." Journal of Emerging Trends in Engineering and Applied Sciences (JETEAS), 3(6): 904-913.

APHA, (1995). Standard Methods for the Examination of Water and Wastewater, $19^{\text {th }}$ Edn. Washington, DC: American Public Health Association.

Chin, D. A. (2006). Water Quality Engineering in Natural Systems. John Wiley \& Sons Inc., New York, USA.

Chindah, A. C., Braide, S. A. and Obunwo, C. C. (2011). Water Quality of Streams Receiving Municipal Waste Water in Port Harcourt, Niger Delta, Nigeria, Waste Water - Evaluation and Management, Prof. Fernando Sebastian Garcia Einschlag (Ed.), In Tech, DOI: 10.5772/16186. http://www.intechopen.com/ books/waste-water-evaluation-andmanagement/water-quality of-streamsreceiving-municipal-waste-water-in-portharcourt-niger-delta-nigeria

Garg, S. (1986). Waste Water Engineering. Khanna Publishers, New Delhi, India.
National Environmental Standards Regulation and Enforcement Agency-NESREA(2011) Surface and Ground Water Quality Control Regulation, Vol. 98, No.136.

O'Connor, D. J. and Dobbins, W. E. (1958). "Mechanism of Re-aeration in Natural Streams." Transactions of the American Society of Civil Engineers, 123:641-684.

Ogbaji, E. O, Jidauna, G. G, Odoh, R. and Agene, E. I. (2013). "Mathematical Modelling of Self Purification of River Benue Water Quality Control." International Journal of Modern Chemistry, 5(2):118-126.

Ogedengbe, K. and Akinbile, C. O. (2010). "Comparative Analysis of the Impact of Industrial and Agricultural Effluents on Ona Stream in Ibadan, Nigeria." New York Science Journal, 3(7):25-33.

Paul, W. (2011). Impact of Industrial Effluents on Water Quality of Receiving Streams in Nakawa-Ntinda, Uganda. M.Sc. Thesis, University of Makerere, Uganda. www: mak.ac.ug/documents/Makfiles/.../ Walakira_Paul.pdf.

Rao, C. S. (2006). Environmental Pollution Control Engineering. New Ages International Publishers Ltd. "2ed. New Delhi, India.

Sharma, M. R, Shamar, R. K., Gupta, A. B. and Bassin, J. K. (2003). "Water Quality Assessment of Hathli Stream in Lower Himalayan region." Journal IAEM, 30: 64-67.

Ubwa, S. T. Atoo, G. H., Ofem, J. O. ,Abah, J. and Asemave, K. (2013). "An Assessment of Surface Water Pollution Status around Gboko Abattoir." African Journal of Pure and Applied Chemistry,7(3): 131-138. 